\title{
Psychological Evaluation of Frisky Robot Motion
}

\author{
Hiroshi Hashimoto Member, Daisuke Takeda Non-member, Yasuhiro Ohyama Member \\ (Tokyo University of Technology, Japan, hiro-hashimoto@ieee.org, takeda@hlab.bs.teu.ac.jp,ohyama@cc.teu.ac.jp) \\ Chiharu Ishii Member (Department of Basic Engineering in Global Environment ,Kogakuin University, Japan, \\ c-ishii@cc.kogakuin.ac.jp) \\ Mihoko Niitsuma Student Member, Hideki Hashimoto Member (Institute of Industrial Science, University of \\ Tokyo, Japan, \{niitsuma, hashimoto\}@hlab.iis.u-tokyo.ac.jp)
}

Keywords: frisky robot, omnidirectional mobile, psychological evaluation, SD method, biosignal, RRV method

This paper describes the emotional evaluation of a frisky robot that weaves around its human owner; the evaluation is based on the SD (Semantic Differential) method and the RRV(R-R wave variance) method using electrocardiograms (ECG) as the biosignal source.

The psychological evaluations are examined for the impression of the moving behavior. In the evaluation, the SD (Semantic Differential) method and the RRV (R-R interval variance) method using the electrocardiogram as biosignal are employed.

The omnidirectional mobile robot with four-wheel drive unit we have developed is shown in Fig.1,.

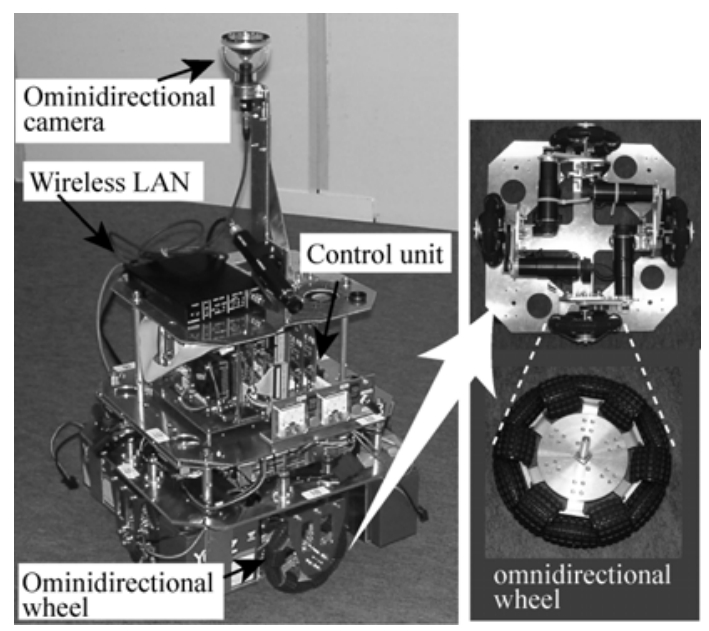

Fig. 1. Omnidirectional mobile robot with four wheel drives

The results of the rating are shown in Fig.2. From the results, it is confirmed that the clinging motion considered as the moving behavior here is able to change the human impression from that in the case of the steady state. Thus, the motion has an important meaning to reveal some impressions.

In the experiments using the RRV method, the RRV grew as the robot be approaching, and then it became small as stopping. Thus, the positive correlation between

the way of the approaching and the sense of secure for the robot is revealed. The evaluation of the impression for the approach angle and the speed. From the results, the relationship between the RRV and sense of secure has positive correlation are revealed as the overall tendency for the results. This leads to that the RRV method is able to be adopt as the real time evaluation method and also be index value for how the robot approach the human.

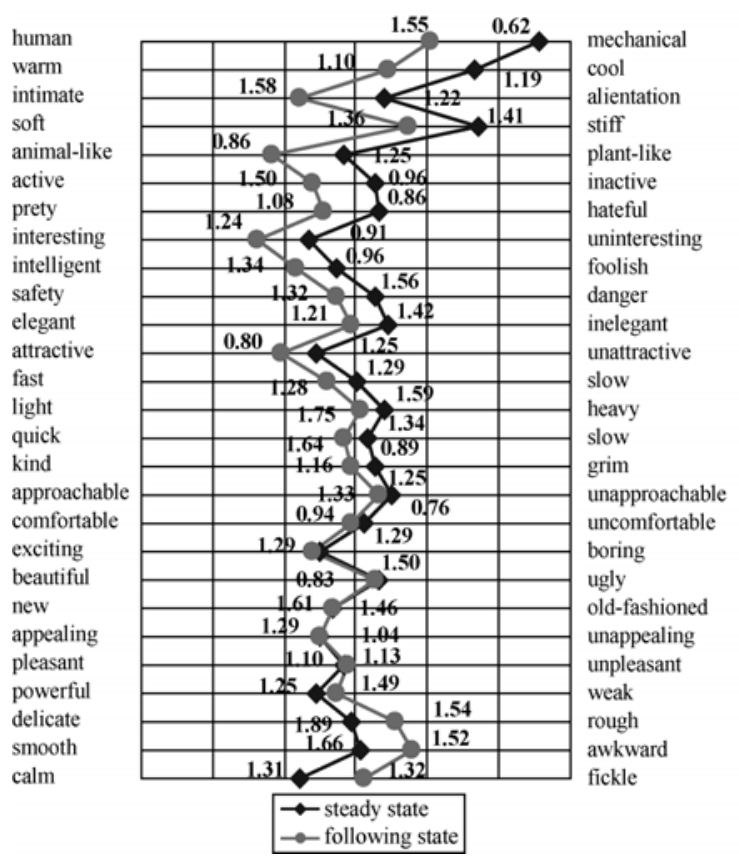

Fig. 2. Results of questionnaire based on the SD method

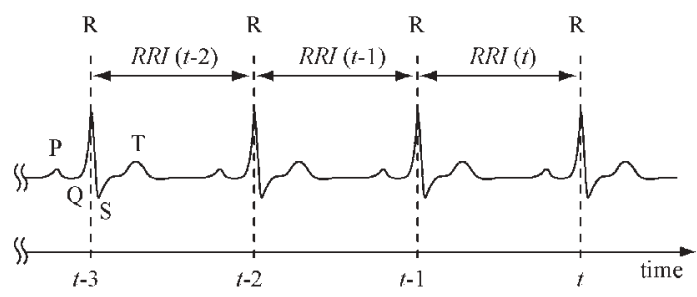

Fig. 3. Typical ECG waveform 


\title{
まつわりつきロボット動作の心理的評価
}

\author{
正 員 橋本 洋志* \\ 非会員 竹田 大祐* \\ 正員大山 恭弘* \\ 学生員 新妻実保子*** \\ 正 員 石井 千春** \\ 正 員 橋本 秀紀***
}

\section{Psychological Evaluation of Frisky Robot Motion}

Hiroshi Hashimoto*, Member, Daisuke Takeda*, Non-member, Yasuhiro Ohyama*, Member, Chiharu Ishii**, Member, Mihoko Niitsuma***, Student Member, Hideki Hashimoto***, Member,

This paper describes the emotional evaluation of a frisky robot that weaves around its human owner; the evaluation is based on the SD (Semantic Differential) method and the $R R V(R \cdot R$ wave variance) method using electrocardiograms (ECG) as the biosignal source. The SD method is effective to measure emotion, and the RRV method is suitable for investigating the physiological state from the heartbeat. The SD method shows that humans show a significant response only when the robot weaves, not when it simply shadows the human. Furthermore, we revealed that these methods are correlated which suggests that the RRV method supports real time evaluation.

キーワード：まつわりつきロボット, 全方位移動, 心理的評価, SD 法, 生体信号, RRV 法

Keywords : frisky robot, omnidirectional mobile, psychological evaluation, SD method, biosignal, RRV method

\section{1. はじめに}

少子高齢化および人口減少(1)が要因となって, 家庭用ロボ ットの需要はますます高まるとの予測調査がある(2)(3)。この 調查では家庭用ロボットのうち, 現在では芝刈り機用や空 拭き用ロボットの需要が一番であるが，今後は家屋の中で 人間の傍にいて, 人間と共に共生するロボットの需要も増 加すると予測している。共生ロボットに要求される仕様と して，人間の良好な体調と活力を維持するためには，人間 の生活活動を全て代替わりするのでなく，その人が有する 能力を最大限に発揮できるような支援が望ましい(4)(5)。こ のためには，ロボットが人間の近傍で常に動いている状態 を想定しなければならないと考える。この場合, ロボット の安全性を確保することはもちろんであるが安心感を人間

* 東京工科大学バイオニクス学部

192-0982 東京都八王子市片倉町 1404-1

School of Bionics, Tokyo University of Technology,

1404-1 Katakura, Hachioji, Tokyo 192-0982

** 工学院大学 国際基礎工学科

下192-8622 東京都八王子市中野町 2647-2

Dep. of Basic Engineering in Global Environment, Kogakuin University,

2647-2 Nakano, Hachioji, Tokyo 192-8622

*** 東京大学 生産技術研究所

$\overline{\mathrm{T}} 153-8505$ 東京都目黒区駒場 4-6-1

Institute of Industrial Science, The University of Tokyo

4-6-1 Komaba, Meguro-ku, Tokyo 153-8505
に与えることも共生する上において重要である。

ロボット動作の安心感に関する従来の研究について, 口 ボットアームの動きに対する安心感の心理的評価(6)(7)では 人間は椅子に座って机上のロボットアームの動きが対象で ある。ロボットとの音声コミュニケーション(8) (10)や視線コ ミュニケーション(11)(12)における心理的評価では, ロボット と人間はほとんど動くことなく主にコミュニケーションの 観点からの心理的評価を行っている。しかしながら, 先に 述べたように人間の近傍での動作に対する心理的評価を行 った研究は見当たらない。

ロボットの動き方について，人間は未知のものや未知の 動き方について不安を感じるので, ロボットの動き方はよ く知られていて親しみやすいものが良い感情を与えるもの と考える。最近の我が国では, ペットロボットがよく知ら れるようになったため, 動物の動きに倣うことが得策と考 える。動物の中でも, 人間の近傍を離れずに動き回るもの として犬のじゃれつき動作があげられる。この動作は, 人 間に対するセラピー効果が高いことが知られており (13), 人 間に良い感情を与えることが充分に期待できる。

そこで, 本研究では，この動きをまつわりつき動作（た だし，人には接触しない）と称し，これを模倣する動きを ロボットで実現し，この動作がどのような印象を人間に与 えるかの心理的評価を行う。まつわりつき動作は四方八方 
に動き回るので，これを実現するには，現在の技術におい て, 全方位移動ロボットが最も適していると考える。また, ロボットと人間との相対位置関係が常に変化することを考 え，人間追従センサとして全方位ビジョンシステムを用い る。さらに, まつわりつき動作には人間に近づいたり離れ たりして，あたかも，摇ら摇らとする動作が必要である。 この動作の実現のため, 仮想インピーダンス法を導入する (14) $\sim(16)$ 。

まつわりつき動作に対する心理的評価すなわち印象度の 項目として, “好ましい”, “親しみやすい”などの複数の項 目があげられる。この評価はよく知られている SD 法 (semantic differential method）(17)を用いて行う。この評 価実験においては, 初めに静止した状態のロボットに対す る印象度評価を行い, この後に, 自由に動き回る被験者に ロボットが追従する様子を被験者が目で見てその印象度評 価を行う。本論文は，この静止状態と追従状態を比較する ことにより, ロボットが動くことによる人間の心理変化に ついて考察する。

まつわりつき動作において，ロボットの近づき方は予想 がつかないことがある。このため, 近づき方によっては被 験者が衝突するかもしれないと思い, 緊張して悪感情を抱 く場合がある。このことは, まとわりつき動作全般が好ま しい感情を与えるとしても, ときとして緊張させることは, 安心動作実現の立場から望ましいものでない。そこで, ど のような近づき方をすると緊張させるかを調べる必要があ る。このため, 近づき方の計測と共に緊張が生じた瞬間を 実時間で計測しなければならない。しかし，SD 法は追従実 験の後にしか評価が行えず，追従している最中の緊張から 生じる悪感情を実時間で評価できない。そこで, この評価 について, 緊張が人間の交感神経を働かせて生理状態を変

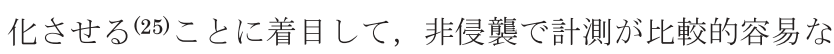
心電図(ECG; electrocardiogram)を用いて緊張度を測るこ ととする。ただし, 緊張により心拍が早まっても, その R-R 間隔(18)は単純には短くならず, ECGの波形は大きく乱れる ため(26)(27)， $\mathrm{R} \cdot \mathrm{R}$ 間隔の分散值に基づく $\mathrm{RRV}$ 法を用いて行 う。RRV 法は作業に対する心的負荷に対しての指標となり うるとの知見が示されている(19)。緊張は心的負荷が過剩な 場合を指すことから，この RRV 法による結果を通して，ど のよう接近が安心感を損なうかの知見を得るものとする。

本論文の構成は次のとおりである。2 章では, まつわりつ き動作の実現について説明する。3 章ではまつわりつき動作 に対する SD 法の評価を行う。 4 章では RRV 法を用いた評 価を行う。

\section{2. まつわりつき動作の実現}

うろうろ動き回る人間の後からロボットが滑らかに追従 できるためにロボットの移動機構を全方位とする。また，人 間とロボットとの相対位置関係は常に変化するからロボッ トから見てどの方向に人間がいてもその位置を画像から特 定できる全方位ビジョンシステムを採用する。さらに，まつ

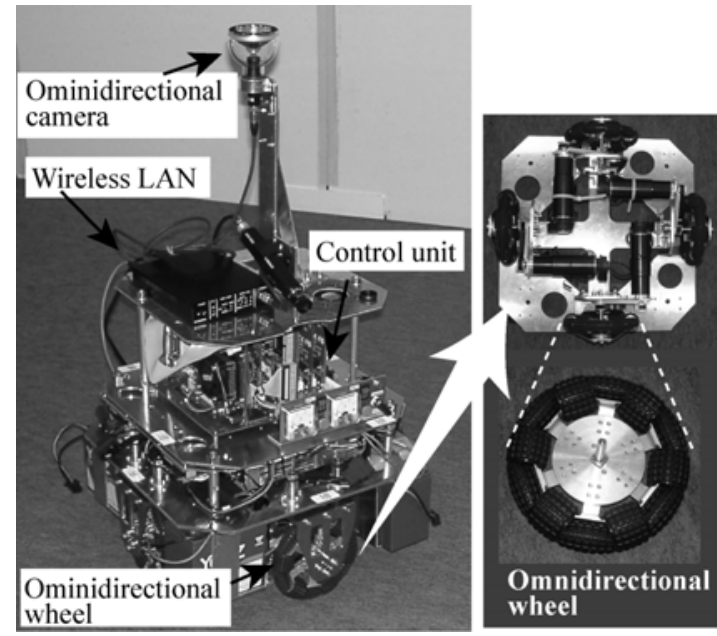

図 1 四つの駆動系を有する全方位移動ロボット

Fig. 1. Omnidirectional mobile robot with four wheel drive units.

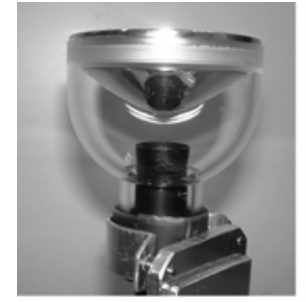

(a) Ominidirectional camera

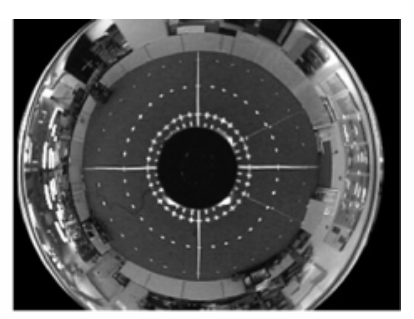

(b) Image from the camera
図 2 全方位ビジョン

Fig. 2. Omnidirectional vision.

わりつき動作を実現するため仮想インピーダンス法を導入 する。これらを装備して開発したロボットの全容を図 1 (左 図）に示す。サイズは約 $1 \mathrm{~m}(\mathrm{H}) \times 45 \mathrm{~cm}(\mathrm{~W}) \times 45 \mathrm{~cm}(\mathrm{D})$ で質 量は約 $30 \mathrm{~kg}$ である。また, 図 1 に示す Control unit には CPU(Pentium III, 1GHz), Memory(256MB), HD(40GB)が 搭載されており, Linux(Vine ver.2.6)上で各部を制御するソ フトウェアを我々が全て開発した。以下, ロボットの各部位 について説明する。

〈2・1〉移動機構全方位ロボットの移動機構は, 図 1 に示すように, 全方位車輪を有する四つの独立駆動系を搭 載し, これにより全方位への移動を可能としている。ロボ ット移動性能は, 最大速度 $1.7 \mathrm{~m} / \mathrm{s}$, 最大加速度 $0.7 \mathrm{~m} / \mathrm{s}^{2}$, 回転角速度 $6.53 \mathrm{rad} / \mathrm{s}$, 回転角加速度 $1.05 \mathrm{rad} / \mathrm{s}^{2}$ である。 これより, 人間の歩行速度を最大 $4 \mathrm{~km} / \mathrm{h}$ （約 $1.1 \mathrm{~m} / \mathrm{s}$ ） と するならば, 人間がうろうろ動き回る後から充分に追従で きる仕様である。

〈2·2〉 ビジョンシステム搭載した全方位カメラを 図 2 に示す。図 $2(\mathrm{~b})$ に示寸画像から, 目標物までの角度と 距離を算出することができる(20)。ここでの目標物は, 図 3 に示すように，人間の足に取り付けた赤色のマーカとした。 また, 床は $6 \mathrm{~m}$ 四方の緑色とし, 緑色と赤色以外はロボッ トが避けるべき障害物とみなすこととした。これについて 


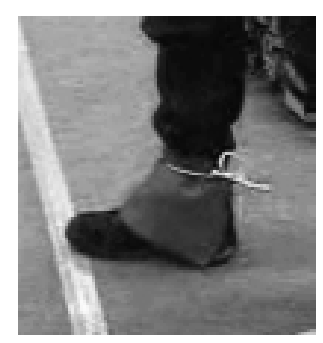

図 3 赤いマーカの目標物

Fig. 3. Red marker as target on ankle.

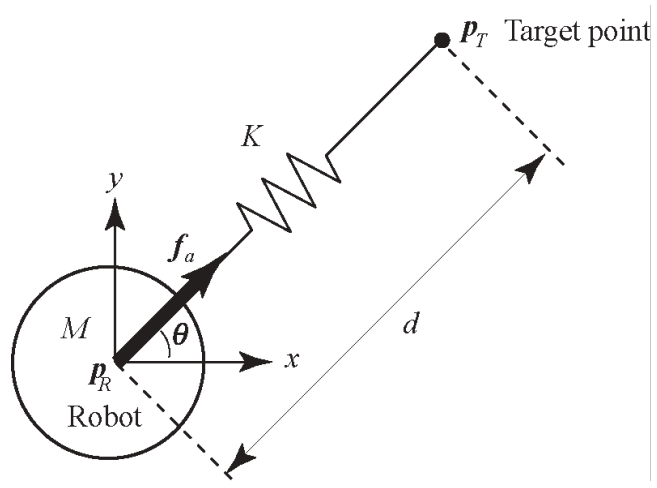

図 4 仮想インピーダンスの説明

Fig. 4. Schematic representation of virtual impedance.

は, 次に詳しく説明する。

〈2·2〉移動力の生成 実時間でまつわり動作を実現 するため，仮想インピーダンス法に基づいた移動を行う。 目標物の位置がビジョンシステムにより得られたとしたと き, 図 4 に示すように，仮想インピーダンスはロボットと 目標物の間に張られる。図 4 の仮想インピーダンスでは粘 性係数を導入していない。この理由は，人間が歩き回った り，ほぼ停止した状態でも，ロボットのまとわりつき動作 としてゆらゆら摇れる動作を実現したいためである。

目標物への引力 $\boldsymbol{f}_{a}$ を次のように計算する。

$$
\left.\begin{array}{c}
M \ddot{\boldsymbol{p}}_{R}=\boldsymbol{f}_{a} \\
\boldsymbol{f}_{a}=\left|\boldsymbol{f}_{a}\right|(\cos \theta, \sin \theta) \\
\left|\boldsymbol{f}_{a}\right|=K\left(d-d_{s t d}\right)
\end{array}\right\}
$$

ここに, $M$ はロボットの質量, $p_{R}$ はロボットの位置, $K$ は 仮想バネ定数, $d$ はロボットと目標物との距離, $d_{s t d}$ は仮想 バネの自然長である。

まつわりつき動作を示すとき，安全第一の観点から人間 などの障害物と衝突しないようにしなければならない。こ のため，障害物を避ける斥力は次のように計算する。図 5 に示すように，ロボットを中心とした円を考え，その最大 半径 $r_{3}$ はビジョンシステムによる最大探査範囲とする。次 に, $r_{1}<r_{2}<r_{3}$ となる $r_{1}, r_{2}$ と $\theta_{\mathrm{seg}}\left(=18^{\circ}\right.$ とおいたので $m$ $=1 \sim 20$ ）用いて図 5 のように円を幾つかのセグメントに分

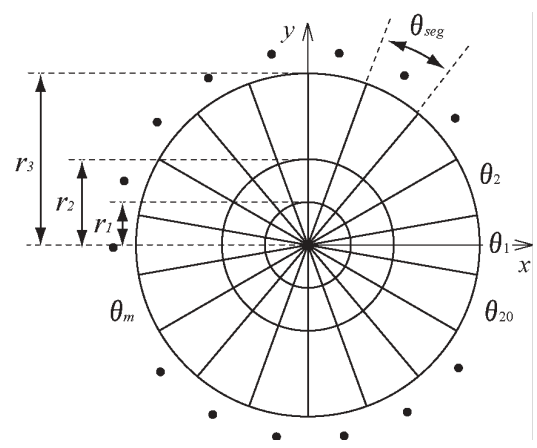

図 5 セグメント分割されたロボットを中心とする 円領域

Fig. 5. Circular region, divided into segments, with center at robot location.

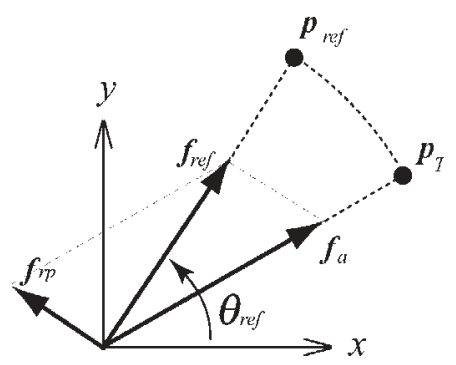

図 6 ロボットの進行方向

Fig. 6. Direction where robot advances with attraction/repulsive forces.

割する。ビジョンシステムは, 各セグメント内の色の頻度 を調べ, 最も頻度の多い色をそのセグメントの代表色とす る。先に述べたように, 代表色が赤ならば目標物と判断し 斥力を計算する。緑ならば床と判断し, 何もしない。これ 以外の色ならば障害物と判断する。この場合, 障害物は人 間 (赤のマーカ以外の部分), 床の外領域などが相当する。

障害物があると判断したセグメントに対し，ロボットと 目標物間の斥力を次で計算する

$$
\begin{aligned}
& \boldsymbol{f}_{r p}^{l, m}=-k_{l} r_{l}\left(\cos \theta_{m}, \sin \theta_{m}\right)^{T} \\
& \text { for each segment } \quad l=1 \sim 3 \quad m=1 \sim 20 \\
& \boldsymbol{f}_{r p}=\sum_{l, m} \boldsymbol{f}_{r p}^{l, m}
\end{aligned}
$$

ここに， $k_{l}$ はゲイン調整用定数である。

ロボットの進行方向 $\theta_{r e f}$ は $\boldsymbol{f}_{a}$ と $\boldsymbol{f}_{r p}$ を用いて図 6 のよう にして求める。すなわち

$$
\theta_{r e f}=\arg \left(\boldsymbol{f}_{a}+\boldsymbol{f}_{r p}\right)
$$

ロボットの方向制御は文献 $(21) \sim(23)$ に基づき行う。その 速度や角度変化の調整は, 実験で使用する床面のすべりや 人間の歩行速度を見て実験的に行うこととした。 


\section{SD 法に基づく評価}

初めに，これまで説明してきたロボット構成でまつわり つき動作を実現できることを示す。次に，まつわりつき動 作に対する心理的評価を SD 法を用いて行う。

〈3.1〉 評価実験の説明実験において, これまで説 明してきたパラメータの值を次のように決定した。予め選 ばれた 5 人の実験者が代表して, 彼らの主観的判断に基づ き, 衝突をしないという条件の下, 良い印象を与えるまつ わりつき動作となるようにパラメータ調整を行った。この 結果, $k=20.0 \mathrm{~N} / \mathrm{m}, k_{1}=20.0 \mathrm{~N} / \mathrm{m}, k_{2}=8.0 \mathrm{~N} / \mathrm{m}, \quad k_{3}=4.0$ $\mathrm{N} / \mathrm{m}, r_{1}=0.5 \mathrm{~m}, r_{2}=1.0 \mathrm{~m}, r_{3}=1.5 \mathrm{~m}$ とした。

実験では，実験者が五つの歩行状態; 静止, 直線歩行, L 字歩行, 長方形歩行, 円歩行を行い, それぞれに対するロ ボットの移動の軌跡を観測した。このうち, 静止状態, 円 歩行状態の結果を図 7 に示す。この結果を見て, ロボット の慣性モーメントと仮想インピーダンス法に基づく引力と 斥力が交互に変化することが要因となり，ロボットはゆら ゆらと摇れながら人間に追従している様子が認められる。 静止状態でもゆらゆらと摇れているのは，被験者が完全停 止に至らず微動したり，また，仮想インピーダンスに粘性 係数を考慮しなかったためと考えられる。

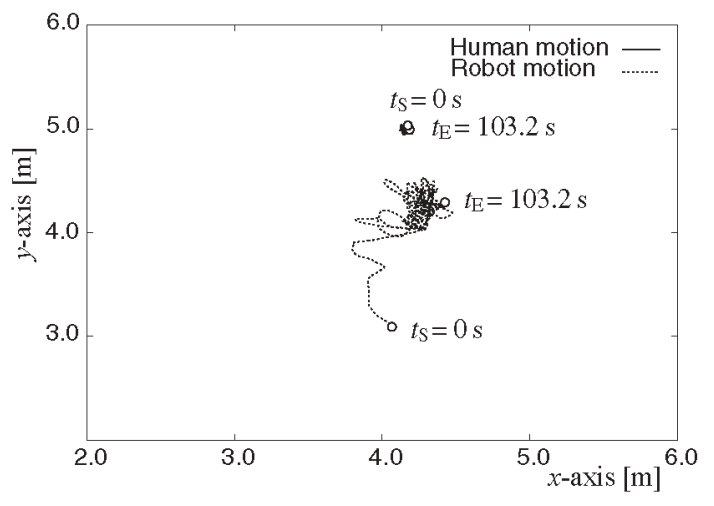

(a) In the case of steady state

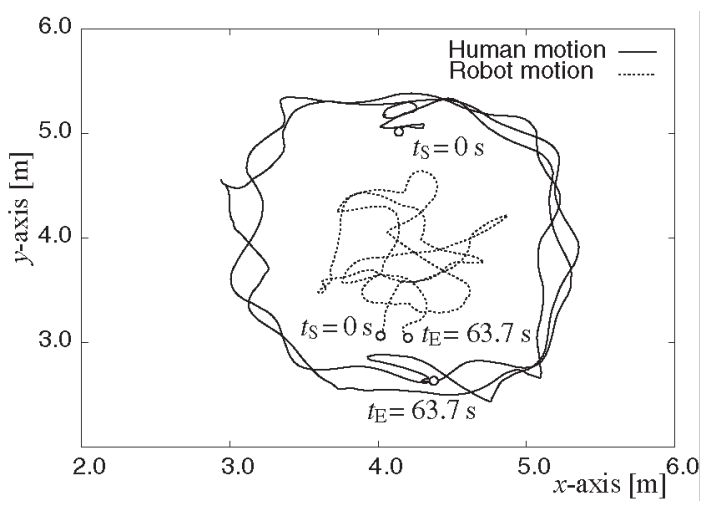

(b) In the case of circular walking state

図 7 被験者とロボットの移動軌跡

Fig. 7. Trajectories of subject and robot.
ゆらゆらと摇れる様子は, 他の例でも同様であった。5人 の実験者より，このような追従の仕方はまつわりつき動作 と認識できるとの回答を得たので，この動作をまとわりつ き動作とする。なお，本実験に参加した実験者は次のアン ケート調査に参加させていない。これは, アンケート内容 に予断を持って判断することを避けるためである。

〈3-2〉 アンケート結果 アンケートの方法は次のよ うにした。1 18 人の被験者（男女 18 歳〜 25 歳）それぞれは, 初めに静止状態のロボットの視覚による印象をアンケート に答える。このアンケートを完了してから, 次に, $6 \mathrm{~m}$ 四方 の床を 5 分間自由に歩き, そのときロボットがまつわりつ き動作をしながら追従する。追従状態の動作を視覚で観測 し，終了後に同じアンケートに答える。アンケート項目は， 図 8 に示すように, 良い感情とその反対の悪い感情を対に した 27 項目に対し， 7 段階の評価值を設定した。ここに， 図 8 の表記は英語であるが，アンケートは日本語で行った。 アンケート結果を図 8 に示す。図において菱形マークは静 止状態, 丸マークは追従状態での印象度の結果の平均值を 示す。また, 数值は各マークの標準偏差である。

この結果を見て, 上から 20 項目は追従状態の方が静止状 態より良い感情を与えており，下から 5 項目は静止状態の 方が良い感情を与えていることがわかる。上から 20 項目の 中には, “暖かい”, “親しみやすい”, “柔らかい”, “かわ いらしい”があり，これら４項目に関する静止状態と追従 状態のアンケート結果の分布を考える。この結果を見ると,

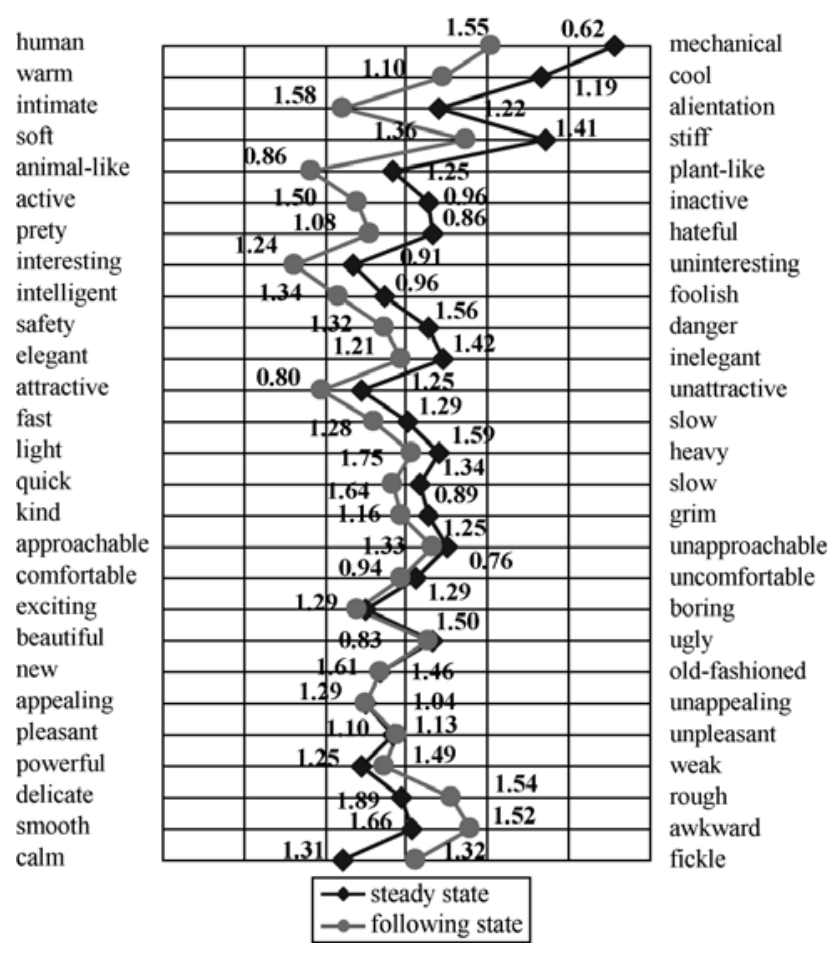

図 $8 \mathrm{SD}$ 法に基づくアンケート結果

Fig. 8. Results of questionnaire based on SD method. 
それぞれの平均值の差に対する二つの標準偏差が十分小さ いため, アンケート結果の分布の広がり具合を見る指標と なる “平均值 $\pm n \times$ 標準偏差” $(1 \leqq n \leqq 3)$ を考えると, 片方 が他方を完全に包含することはないことがわかる。すなわ ち, 統計的には少なくともこの 4 項目について, 静止状態 と追従状態とでは被験者が抱く感情が異なるものと考えて よいことが言える。このことを踏まえて，ロボットの外見 が図 1 のように，機械的であるにも関わらず，このような 良い感情を抱かせるのはロボットの動きが要因であると指 摘できる。また，“動物的”という印象も強く認められ，少 なくとも犬に代表されるような動物を印象付けられたこと は，まつわりつき動作の導入目的が達成されたと考える。

下の 5 項目のうち, “力強い”, “落ち着いた” は静止した 機械を視認したときに必然的に生じる感情と考えられる。

“䋊細”, “滑らかな”は移動の仕方や設計パラメータの設 定に改善の余地があることを指摘している。

以上より，開発したロボットの外見が非常に機械的であ るにも関わらず，動くことにより，人間は静止状態と異な る感情を抱くとの結果を得た。しかも，本実験のようにま つわりつき動作は人間に良い感情を与えることがアンケー ト結果から認められた。

しかしながら，“感じの悪い”，“気持ちの悪い”という 悪感情に改善が認められず, このときの感情内容を実験後 に問診すると，ロボットがぶつかるのではという不安感か らの緊張が生じ，これを先の二つの言葉で回答したという 問診結果を得た。そのため, このような悪感情が生じるの は, まつわりつき動作のうちのどのような動きに起因する かを調べる実験を次に行う。

\section{RRV 法による評価}

ECG の一般例を図 9 に示す。緊張が生じたときの人間の ECG について, 正常時や安静時のときよりも心拍が早くな るが, 図 9 の RRI $(t)$ は単純に短くならず, QRST 間隔が大き

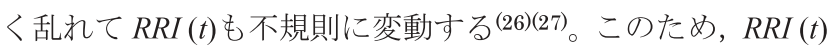
の変動分の指標として, 以下に説明する $R R V(t)$ を採用する。 $\mathrm{ECG}$ 波形の $R$ 波の周期に関する短区間での分散值を用い る $R R V(t)$ を次に定義する。

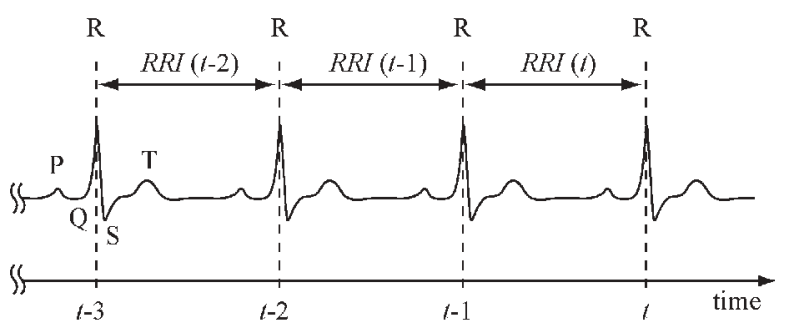

図 9 ECG の一般例

Fig. 9. Typical ECG waveform.

$$
R R V(t)=\frac{\sum_{i=0}^{N-1}(R R I(t-i)-\overline{R R I}(t))^{2}}{N-1}
$$

ここに, $\overline{R R I}(t)$ は次で定義される時刻 $t$ における周期の平 均值である。

$$
\overline{R R I}(t)=\frac{\sum_{i=t-N+1}^{t} R R I(i)}{N}
$$

また,標本数 $N$ は，参考文献(19)を参考にして 16 とした。

被験者は 3 人とし, 被験者の心臓周辺の皮膚に生体電極 を取付け，この電極信号を実時間でコンピュータに取り込 み ECG を観測し，これから式(5),(6)を計算する。

次に, ロボットの被験者への接近方法について説明する。 まつわりつき動作では, 人間の心理が他者に及ぼす距離を 考慮する必要があると考える。この距離を決める指針とし て, 心理学のパーソナルスペースがある(28)。これを参考に して移動ロボットは人間との距離を $0.5 \mathrm{~m} \sim 3.5 \mathrm{~m}$ の範囲で 動くこととした。

図 10 に示すように, 被験者から $3.5 \mathrm{~m}$ 離れた地点で被験 者に対し $0^{\circ}, 30^{\circ}, 60^{\circ}$ の 3 地点 $\mathrm{A}, \mathrm{B}, \mathrm{C}$ をロボットの出 発点とする。ロボットは出発点から被験者に向かって直線 上を移動し， $0.5 \mathrm{~m}$ 手前で停止するようにした。このときの ロボットの最大接近速度を高速 $(0.6 \mathrm{~m} / \mathrm{s})$ とその半分であ

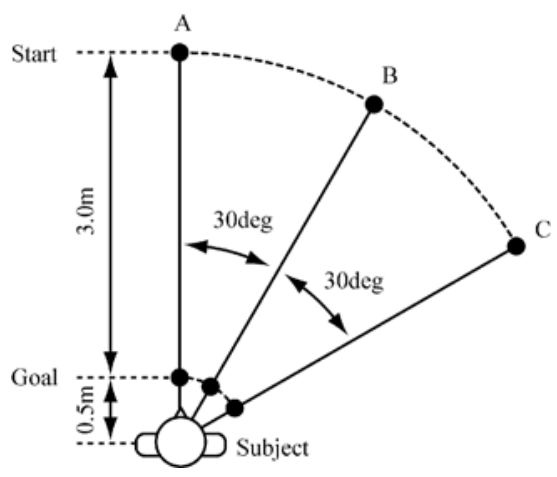

図 10 ロボットの出発点と停止点

Fig. 10. Start and stop points for robot.

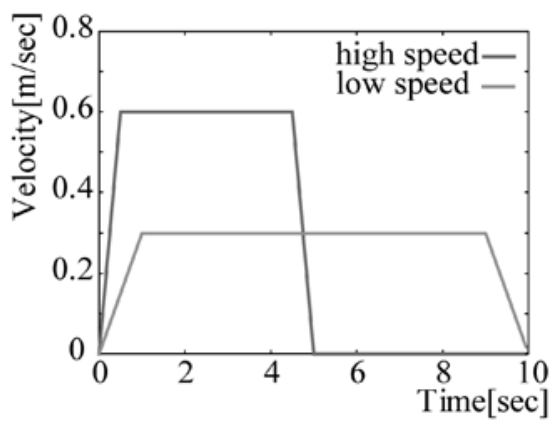

図 11 接近速度パターン

Fig. 11. Patterns of approach speed. 


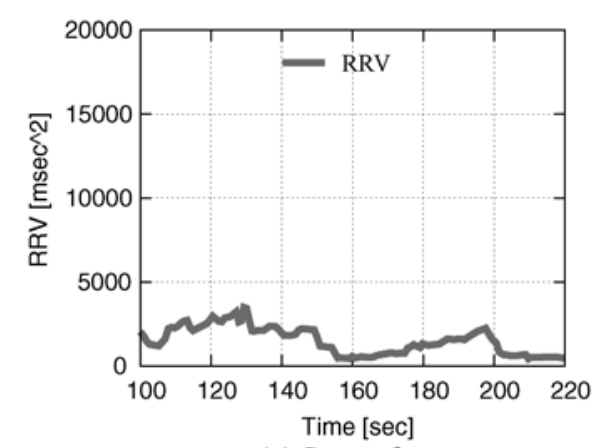

(a) State of rest

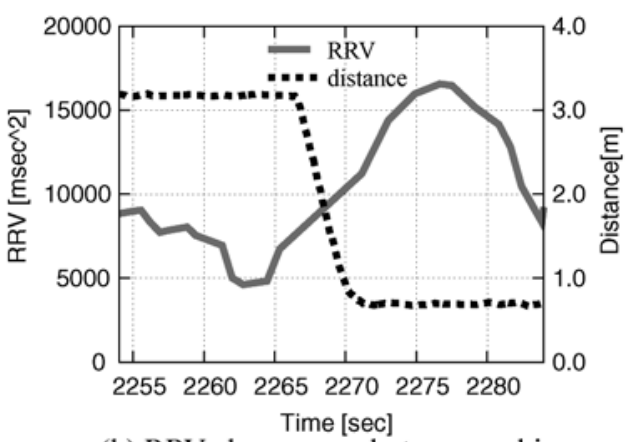

(b) RRV change as robot approaching

図 12 被験者 I 9 実験結果, 進入角度 $60^{\circ}$, 高速 度の場合

Fig. 12. Results of subject I, approach angle $60 \mathrm{deg}$, high speed.

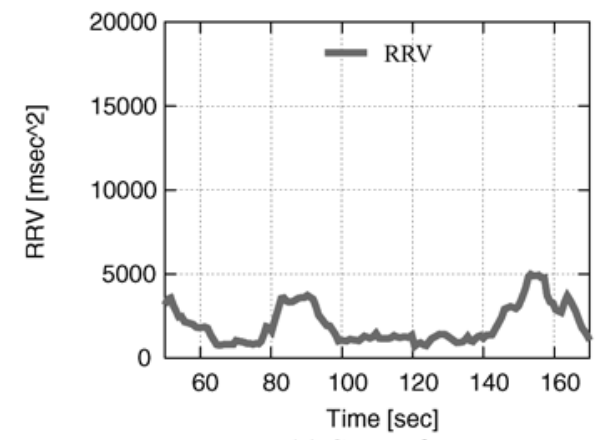

(a) State of rest

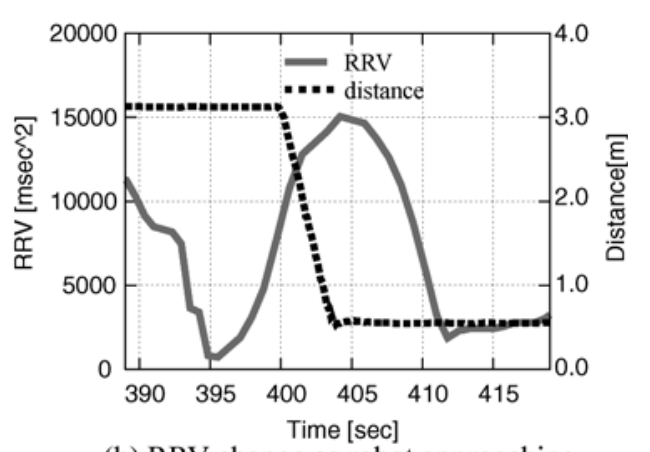

(b) RRV change as robot approaching

図 13 被験者 II の実験結果, 進入角度 $0^{\circ}$, 高速 度の場合

Fig. 13. Results of subject II, approach angle 0 deg., high speed.
る低速 $(0.3 \mathrm{~m} / \mathrm{s})$ の 2 種を用意した。移動距離が $3.5 \mathrm{~m}$ から $0.5 \mathrm{~m}$ までの $3 \mathrm{~m}$ であることから, 図 11 に示寸ような速度パ ターンとなる。これらより, 1 人の被験者に対して, 出発点 が 3 通り, 速度パターンが 2 通りの計 6 通りの接近実験を 行った。

接近実験に先立ち, $R R V(t)$ の平静時波形を基準とするた め, ロボットを Start 地点で停止させたまま, 被験者を 1 分間安静にした後に $R R V(t)$ を 2 分間計測した。この後に接 近実験を行った。 $R R V(t)$ の波形に特徵的変化が現れたのは, 高速の速度パターンで接近する場合であった。この例を図 12,13 に示す。どちらも図(a) は平静時の $R R V(t)$ 波形, 図(b) はロボットが近づいてきたときの $R R V(t)$ とロボットと被験 者との距離を示す。この二つの例を見て, $R R V(t)$ が平静時 と明らかに異なる形状を示している。すなわち, 図(b)につ いて，ロボットが近づき始める直前から被験者はロボット を注視しているので, 近づくことを意識し始めたことに起 因して $R R V(t)$ が高い值を示す。これがグラフの初期值が高 いことの理由である。その後に, 一度 $R R V(t)$ が低下するの は，心的または肉体的に過負荷がかかっていない状態では 数秒以内 $\mathrm{R}-\mathrm{R}$ 間隔と QRST 間隔を正常に戻そうとする人間 の一般的な生理現象によるものである(25),(26)。その次に，口 ボットが接近を開始すると, 今までの中で最も高い $R R V(t)$ が観測され，接近時に最も緊張が高まったものといえる。

他の例では, 平静時と接近時とで $R R V(t)$ の区別がつきに くい場合もあった。特に, 低速度接近の場合には, 有意な 区別はできなかった。これは, 接近に対する感情は, 被験 者の経験や背景さらには試行回数に依存するため, 接近時 に必ずしも $R R V(t)$ に変化が生じるわけではないが, 少なく とも $R R V(t)$ が変化したならば，ロボットに対して緊張感を 感じているという十分条件を指摘できる。

次に, 接近角度と速度という因子と「好感, 嫌悪」, 「安心, 緊張」の 2 項目 7 段階との相関性のアンケート調查した結 果を図 14 に示す。図中の数字は標準偏差を表す。またグラ フの表記は英語であるがアンケート調査では日本語を用い た。

図 14(a),(b)の結果を見ると, 悪い感情となるのは, 速度 に関しては当然のことながら低速よりも高速の場合であ る。接近角度に関しては正面よりは横から接近するほうに 強く出るという傾向が認められる。特に, 図 14(b)の緊張度 についてみると, 接近速度が低い場合は, 接近角度が 60 度 までならば, “安心”感が強いが, 接近速度が 2 倍になると 接近角度が 0 度でも, “緊張” が高いという傾向が認められ る。これらのことをまとめると, 接近角度が大きくなるに つれて悪い感情が高まるが, 低速度であるならば, その度 合いは低く良い感情を保てるといえる。したがって, 人間 に安心感を与えるまつわりつき動作とは，接近角度が大き くなった場合には速度の低減が必須といえる。

接近角度について, 駅前などでビラやティッシュを配る 場合, 歩行者の進行を妨げない, また, 正面から接近する と殺傷などの不安感から身構えてしまう, という理由から, 


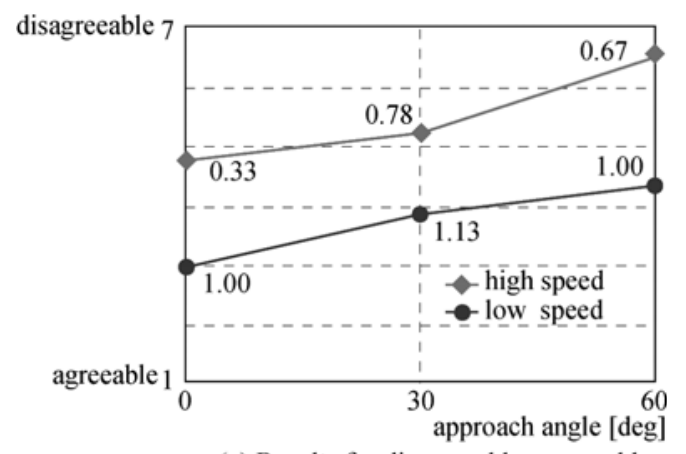

(a) Results for disagreeable - agreeable

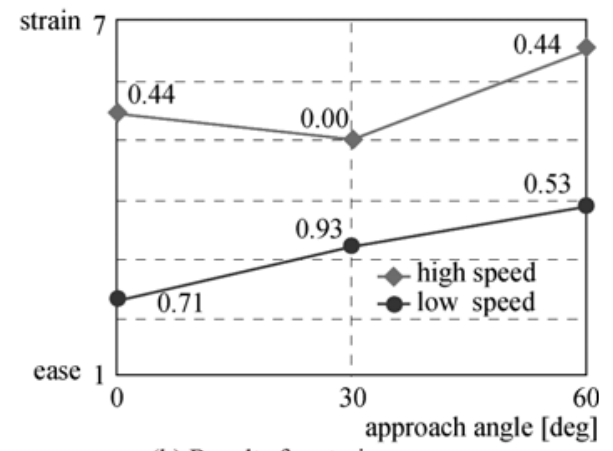

(b) Results for strain - ease

図 14 アンケートによる印象度 v.s.接近角度・速度

Fig. 14. Results of questionnaire: impression v.s. approach angles for high and low speed.

配る人は歩行者の横から接近する。しかし,この場合，配る 人に対して一瞥して“配る”という動作だけを行う人間と 認識すれば，正面にいない方が悪い感情は生じない(24)。

一方，本実験結果ではこれと逆の結果を示している。視 力は横に行くほど低下するため, 人間ではない未知の物体 が横から接近してくるのは悪い感情が生じやすいと考えら れる。

\section{5. おわりに}

本論文は，全方位移動機構に基づくまつわりつき動作を 示すロボットの実現を図り，この動作に対する心理的評価 を行った。その実験結果に対する考察を通して得られた知 見は，ロボットが静止しているときには機械的印象を与え ていたが，動物を連想させるまつわりつき動作を示すこと により，当初に予想したとおり，人間に好印象を与えると いう感情の変化が認められたことである。このことから, 共生ロボットの設計因子には, 外観, 肌触り, 鳴き声のみ ならず動き方も重要であることが指摘できる。

さらに，人間への近づき方について，横からの接近は悪 い感情を与えるが，これも接近速度によりその度合いが異 なるという結果を得た。一方, 行為の意図が外観から明白 な人間が他人に近づくときには横からの接近の方が安心感 を得る場合もあるため, 今後は，この要因をさらに分析し て，ロボット動作に反映させることにより，ロボットの接 近角度に対する悪感情の発生度を小さくして,まつわりつき
動作全般の安心感をさらに高める動作設計論を確立する予 定である。

最後に, 査読者からの貴重なご指摘により, 本論文の内 容を高めて頂いたことに感謝します。

(平成 17 年 3 月 23 日受付, 平成 17 年 9 月 12 日再受付)

\section{文献}

(1) Database of Ministry of Health, Labour and Welfare in Japana, http://www.mhlw.go.jp/english/index.html

(2) United Nations Economic Commisiion for Europe, 国連欧州経済 委員会, http://www.unece.org/

(3) International Federation of Robotics, 国際ロボット連盟, http://www.ifr.org/

(4) T.Matsunaga : "View of advanced interface technology which supports advanced activity of elderly in Japan", SICE Annual Conference of System Integration (2004) (in Japanese) 松永：「高齢者の高度活動を支援する高度インタフェース技術の展 望」，SICE SI 部門講演会，(2004)

（5）藤原・碓井・立野：身体機能の老化と運動訓練〜リハビリテーショ ンから健康增進まで〜，日本出版サービス（2000)

(6) R.Ikeura, H.Otsuka, and H.Inooka : "Study on emotional evaluation of robot motions based on galvanic skin refex", Japan Ergonimics Society, Vol.31, No.5, pp.355-358 (1995) (in Japanese) 池浦・大塚・猪岡 :「皮膚電気反射に基づくロボット運動の心理的評 価に関する考察」, 日本人間工学, 31, No.5, pp.355·358 (1995)

(7) Y.Yamamoto, S.Shibata, M.Jindai, and A.Shimizu "Psychological Analysis of Avoidance Motion of RObots Using Semantic Differential Method", JSME(C), Vol.66, No.650, pp.3366-3372 (2000) (in Japanese)

山本・柴田・神代・清水：「SD 法を用いたロボットの人間回避運動 の心理的分析」, 日本機械学会論文集 (C), 66, No.650, pp.3366-3372 (2000)

(8) T.Shibata, et al.: "Artificial Emotional Creature for HumanMachine Interaction", Proc. IEEE System, Man, and Cybernetics, pp.2269-2274 (1997)

(9) S.Shibata et al.: "Psychological evaluation of robot motions", Int. J. of Industrial Ergonomics, Vol.21, pp.483-494 (1998)

(10) H.Kobayashi, et al.: "A Basic Study on Dynamic Control of Facial Expressions for Face Robot", Proc. IEEE Int. Workshop on Robot and Human Communication, pp.275-280 (1995)

(11) T.Kanda, et al.: "Psychological Analysis on Human-Robot Interaction", IEEE Int. Conf. on Robotics and Automation, pp.4166-4173 (2001)

(12) T.Kanda, et al.: "Development and Evaluation of Interactive Humanoid Robots (Invited paper)", Proc. of the IEEE, Vol.92, No.11, pp.1839-1850 (2004)

(13) CENCHARE, Univ. of Minnesota (http://www.censhare.umn. edu/), Therapy Dogs International, Inc. (http://www.tdi-dog. org/) and so on

(14) O.Khatib : "Real-Time Obstacle Avoidance for Manipulators and Mobile Robots", The Inter. Jour. of Robotics Research, Vol.5, No.1, pp.90-98 (1986)

(15) T.Arai and J.Ohta : "Motion Planning of Multiple Mobile Robots Using Virtual Impedance", The Robotics Society of Japan, Vol.11, No.7, pp.1039-1046 (1992) (Japanese)

(16) H.R.Everett : "Sensors for mobile robots: theory and applications", A.K.Peters, Ltd. (1995)

(17) J.G.Snider, et al: "Semantic differential technique", Aldine Publishig, (1969)

(18) Y.Goshima and K.Ohbayashi : "ABC of ECG", Japan Medical Association (1999)

(19) M.Hirose and T.Ishii : "A Method for Objective Assesment of Mental Work", JSME(C), Vol.51, No.471, pp.3153-3161, 1990 (in Japanese) 
広瀬・石井 :「知的作業の客観的評価の手法」, 日本機械学会論文中

(C), Vol.51, No.471,pp.3153-3158 (1990)

(20) B. Krose, R. Bunschoten, S. T. Hagen, B.Terwijn, and N. Vlassis "Household Robots Look and Learn" IEEE Robotics \& Automation Magazine, pp. 45-53 (2004-12)

(21) C. Belta : "Geometric Methods for Mulit-Robot Planning and Control", Doctor thesis, Mechanical Engineering and Applied Mechanics, University of Pennsylvania (2003)

(22) S. Fujisawa, K. Ohkubo, Y. Shidama, and H.Yamaura "Kinematics and Moving Properties of a Four-Wheel-Drive, Omnidirectional Mobile Robot", The Japan Society of Mechanical Engineering, part-C, Vol.62, No.604, pp.149-156, 1996 (in Japanese)

藤沢・大久保・師玉・山浦 : 「四輪独立駆動型全方位移動ロボットの 運動学と走行特性」, 日本機械学会論文集 (C), 62, No.604, pp.4573-4579 (1996)

(23) J. Tang, K. Watanabe, K. Kuribayashi, and Y. Shiraichi : "Autonomous Control for an Omnidirectional Mobile Robot with the Orthogonal-Wheel Assembly", The Robotics Society of Japan, Vol.17, No.1, pp.51-58, 1999 (in Japanese)

湯・渡辺・栗林・白石：「直交車輪機構を用いた全方位移動ロボット 車の自律制御」, 日本ロボット学誌, 17, No.1, pp.51-60 (1999)

(24) 吉森 : 人間関係の心理学ハンディブック，北大路書房 (1996)

(25) 自律神経機能検查 (第 3 版), 日本自律神経学会編, 文光堂 (2000)

（26）五島・大林・監修：改訂版心電図の $\mathrm{ABC}$, 日本医師会発行 (2003)

（27）藤原・外山：改定身体活動と体力トレーニング(15 章), 日本出版サ 一ビス (2004)

（28）深田博巳：インターパーソナル・コミュニケーション，対人コミュ ニケーションの心理, 北大路書房 $(2000)$

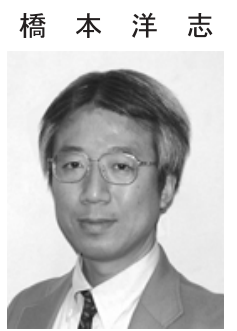

（正員） 1960 年 2 月 28 日生。 1988 年 3 月早 稲田大学大学院理工学研究科博士後期課程単 位取得後退学。同年 4 月早稲田大学理工学部助 手, 1990 年東京工科大学専任講師, 1995 年助 教授，現在に至る。工学博士。1990 年 1998 年早稲田大学理工学総合センター客員研究員。 2003 年より理化学研究所客員研究員。バイオ ロボット, サイバネティックインタフェース, ディジタル空間, 福祉工学に従事。日本 e-Learning 学会理事。 IEEE, 計測自動制御学会, 電子情報通信学会, 日本ロボット学会 各会員。(http://www.teu.ac.jp/hiha/ 参照)

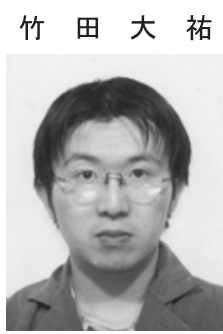

（非会員） 1979 年 8 月 6 日生。 2004 年 3 月東 京工科大学大学院修士課程卒業。同年 4 月同大 学大学院博士後期課程。群ロボット, 生体イン タフェースを用いたコミュニケーションの研 究に従事。

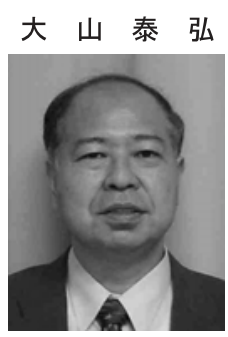

(正員) 1956 年 6 月 30 日生。 1985 年 3 月東 京工業大学大学院理工学研究科博士課程修了。 同年(株)アドバンストコントロールラボラトリ 入社, 1987 年取締役就任。産業用ロボットコ ントローラ, NC コントローラ, 制御工学学習 機器の開発に従事。1991 年 4 月東京工科大学 工学部機械制御工学科講師を経て, 現在, 東京 工科大学バイオニクス学部教授。工学博士。福 祉制御機器, ロボティクス, オンライン教育システムに関する研究 に従事。

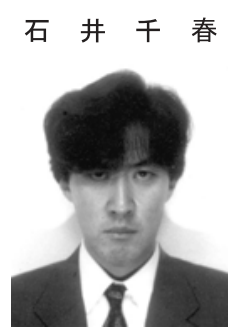

（正員） 1969 年 5 月 22 日生。 1994 年 3 月上 智大学大学院理工学研究科博士前期課程修了。 1997 年 3 月同大学大学院理工学研究科博士後 期課程修了。同年 4 月足利工業大学講師。2002 年 4 月工学院大学工学部国際基礎工学科講師, 2005 年 4 月同大学同学部同学科助教授, 現在 に至る。博士 (工学)。ロバスト制御理論およ びそのロボットへの応用, 医療福祉機器の研究 に従事。IEEE, 計測自動制御学会, 日本ロボット学会, 日本機械 学会各会員。

新 妻 実保子

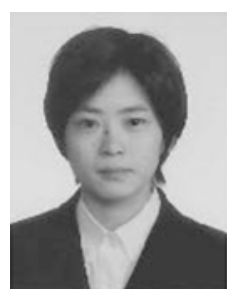

橋 本 秀 紀 (正員) 1957 年 8 月 15 日生。 1981 年 3 月東

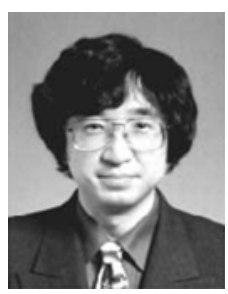
京大学工学部電気工学科卒業。1987 年同大学 大学院工学系研究科電気工学専攻博士課程修 了。工学博士。同年 4 月同大学講師。東京大学 生産技術研究所勤務。1990 年同大学助教授, 現在に至る。1989-90年MIT 客員研究員 (LIDS, LEES)。知的制御システム, 制御工学, Robotics 及び空間知能化の研究に従事。IEEE，計測自 動制御学会, 日本ロボット学会各会員。(http://dfs.iis.u-tokyo.ac.jp/ 参照) 